\title{
The Winning of Empty Box in the 2018 Makassar Regional Head Election
}

\author{
Harianto 1,* (D) Wawan Budi Darmawan 2, (D) and Muradi ${ }^{3}$ \\ ${ }^{1}$ Master of Political Science, Faculty of Social and Political Sciences, \\ Universitas Padjadjaran, 45363, West Java Province, Indonesia \\ 2 Department of International Relations, Faculty of Social and Political Sciences, \\ Universitas Padjadjaran, 45363, West Java Province, Indonesia \\ ${ }^{3}$ Department of Political Science, Faculty of Social and Political Sciences, \\ Universitas Padjadjaran, 45363, West Java Province, Indonesia \\ * Corresponding Author: harianto18001@mail.unpad.ac.id
}

\section{ARTICLE INFO}

\section{Publication Info:}

Research Article

How to cite:

Harianto, H., Darmawan, W. B., E Muradi, M. (2020). The

Winning of Empty Box in the 2018 Makassar Regional Head Election. Society, 8(2), 546-556.

DOI: $10.33019 /$ society.v8i2.203

Copyright (C) 2020. Owned by Author(s), published by Society

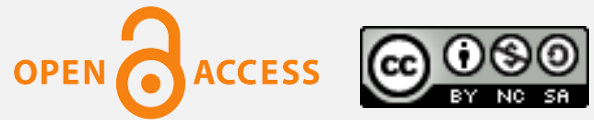

This is an open-access article.

License: Attribution-

NonCommercial-ShareAlike (CC BY-NC-SA)

Received: June 27, 2020;

Accepted: October 21, 2020;

Published: December 22, 2020;

\section{ABSTRACT}

This research discusses how the empty box won in the 2018 Makassar Regional Head Election. This phenomenon became the elections' history where a single candidate failed to win the election. Ten political parties consisting of Functional Groups Party (Golkar), National Democratic Party (NasDem), Indonesian Democratic Party of Struggle (PDI-P), United Development Party (PPP), Crescent Star Party (PBB), Great Indonesia Movement Party (Gerindra), Prosperous Justice Party (PKS), People's Conscience Party (Hanura), National Mandate Party (PAN), and Indonesian Justice and Unity Party (PKPI), promoted a single candidate pair. This study aims to describe how the movement of empty box volunteers in the Makassar Regional Head Election. This research uses a qualitative method. Selection of informants using a snowball sampling technique, and using social movement theory. There are three parts to this theory: 1) Complaint theory. Public disappointment over a candidate pair's disqualification and consider the election organizer unfair; 2) Mobilizing structures theory. Analyze the voluntary movement of empty boxes to gather mass support and sympathizers during the election; and 3) Framing theory. Analyze the use of issues and methods of spreading the issue. This research found that the empty box phenomenon in Makassar Regional Head Election, unlike in the elections in other areas where the single candidate did not have an opponent, in Makassar, one of the candidate pairs was disqualified due to violation. It made the community, supporters, and the success team feels disappointed with the 
General Elections Commission's decision. This disappointment also resulted in the emergence of the empty box volunteer movement. Movements of empty box volunteers to gather mass support and sympathizers through door-to-door socializing, leaflets, flyers, and banners call to action to win empty box and use social media and online media as campaign tools.

Keywords: Empty Box; Simultaneous Regional Election; Single Candidate Pair; Social Movement; Volunteer

\section{Introduction}

General elections or elections, according to India Samego, are also called "Political Marketing." General elections are political markets where individuals/communities interact to carry out social contracts (people agreements) between general election participants (political parties) and voters (people) who have the right to vote after first carrying out a series of political activities (Rahman, 2007).

The general election system is one of the systems for people to elect their representatives. In legislative elections, the electoral system transfers the number of votes into the number of seats in the legislative institutions, whereas in the elections for the President, Governor, and Regent/Mayor, the number of votes obtained is the determinant of victory in general elections (Gaffar, 2006).

Simultaneous regional elections are one of the developments in general elections in Indonesia. One of the goals of the simultaneous regional elections is to save the state budget. Simultaneous regional elections have been running for three periods since 2015, 2017, and 2018. Simultaneous regional elections gave rise to a new term; a single candidate pair competed with an empty box. In the 2015 simultaneous regional elections, the term empty box has not yet appeared. If there is a single candidate pair, the ballot papers will only display options agree and disagree at the bottom of a single candidate pair's picture (Badan Pengawas Pemilihan Umum Republik Indonesia, 2015). Only then, in the next simultaneous regional elections in 2017 and 2018, the ballot papers display a single candidate pair's picture side by side with an empty box (Komisi Pemilihan Umum Republik Indonesia, 2017).

In the 2015 simultaneous regional elections, consisting of governor elections, mayor elections, and regent elections, covering 269 regions consisting of 9 provinces, 36 cities, and 224 regencies (Dirgantara, 2015; Suara.com, 2015). In the 2017 simultaneous regional elections covering 101 regions consisting of 7 Provinces, 18 Cities, and 76 Regencies (Widyasari et al., 2019; Liputan6.com, 2016). In the 2015 simultaneous regional elections, there were three regions with single candidate pairs, namely Blitar Regency, Tasikmalaya Regency, and North Central Timor Regency (CNN Indonesia, 2015).

Then in the 2017 simultaneous regional elections, there were nine regions with a single candidate pair, including Pati Regency (Darmawan, 2017), Tulang Bawang Barat Regency, Landak Regency, Buton Regency, Tebing Tinggi Regency, Tambrauw Regency, Jayapura City, and Sorong City (Komisi Pemilihan Umum Republik Indonesia, 2016). Whereas in the 2018 simultaneous regional elections covering 171 regions and 16 of them with a single candidate pair.

Copyright ( ) 2020. Owned by Author(s), published by Society. This is an open-access article under the CC-BY-NC-SA license. 
Table 1. Number of Regions and Regional Head's End of Period in the 2018 Simultaneous Regional Elections

\begin{tabular}{|c|c|c|c|c|}
\hline \multirow{2}{*}{ No } & \multirow{2}{*}{ Regional Category } & \multicolumn{2}{|c|}{ Regional Head's End of Period } & \multirow{2}{*}{ Number of Regions } \\
\cline { 3 - 5 } $\mathbf{1}$ & Province & $\mathbf{2 0 1 8}$ & $\mathbf{2 0 1 9}$ & 17 \\
\hline $\mathbf{2}$ & Regency & 78 & 37 & 115 \\
\hline $\mathbf{3}$ & Municipality & 29 & 10 & 39 \\
\hline \multicolumn{2}{|c|}{ Number of Regions } & $\mathbf{1 1 9}$ & $\mathbf{5 2}$ & $\mathbf{1 7 1}$ \\
\hline
\end{tabular}

Source: Detik.com (2017)

Based on Table 1, the number of regions in the 2018 simultaneous regional elections was 171 regions, consisting of 17 provinces, 115 regencies, and 39 municipalities.

Table 2. Number of Regions with Single Candidate Pair in the 2018 Simultaneous Regional Elections

\begin{tabular}{|c|c|c|}
\hline No & Region Name & Regional Category \\
\hline $\mathbf{1}$ & Deli Serdang & Regency \\
\hline $\mathbf{2}$ & Padang Lawas Utara & Regency \\
\hline $\mathbf{3}$ & Prabumulih & Regency \\
\hline $\mathbf{4}$ & Pasuruan & Municipality \\
\hline $\mathbf{5}$ & Tangerang & Regency \\
\hline $\mathbf{6}$ & Tangerang & Regency \\
\hline $\mathbf{7}$ & Lebak & Regency \\
\hline $\mathbf{8}$ & Tapin & Regency \\
\hline $\mathbf{9}$ & Minahasa Tenggara & Regency \\
\hline $\mathbf{1 0}$ & Enrekang & Municipality \\
\hline $\mathbf{1 1}$ & Makassar & Regency \\
\hline $\mathbf{1 2}$ & Mamasa & Regency \\
\hline $\mathbf{1 3}$ & Mamberamo Tengah & Regency \\
\hline $\mathbf{1 4}$ & Puncak & Regency \\
\hline $\mathbf{1 5}$ & Jayawijaya & Regency \\
\hline $\mathbf{1 6}$ & Bone & \\
\hline & & \\
\hline
\end{tabular}

Source: Liputan6.com (2018b) 
Table 2 shows 16 regions with a single candidate pair in the 2018 simultaneous regional elections in the regency/municipality category. Single candidate pairs occurred in simultaneous regional elections in 2015, 2017, and 2018. However, only in the 2018 simultaneous regional elections, an empty box won against single candidate pair. The winning of an empty box has become a historical record in Indonesia's election, where a single candidate pair has lost against an empty box for the first time. It is interesting to research that the empty box is only a rectangular picture and has succeeded in winning.

The single candidate pair in the 2018 Makassar regional head election, Munafri Arifuddin, paired with Andi Rachmatika Dewi or better known as Appi-Cicu, is supported by ten political parties, namely Golkar, NasDem, PDI-P, PPP, PBB, Gerindra, PKS, Hanura, PAN, and PKPI (Kompas, 2018a). Munafri Arifuddin is the son-in-law of Aksa Mahmud, owner of the Bosowa Group. Aksa Mahmud is the brother-in-law of Muhammad Jusuf Kalla, Vice President of Indonesia, in 2 periods, 2004-2009 and 2014-2019 (Kompas.com, 2017).

Several previous studies have relevance to this research. First, the factor that causes a single pair of candidates or empty boxes is the cancellation of support from PKPI for issue recommendations for two candidate pairs (Mara, 2018). Second, focus on public participation in the elections: electoral activity, lobbying, organizational activity, contacting, and violence, and also efforts to win empty boxes (Khaerah et al., 2019). Third, focus on the occurrence of single candidate pairs or empty boxes, but there are differences. This study found three factors: Institutional Factors, Political Party Factors, and Power Egoism (Damanik, 2018).

This current research position is to expand and enrich the literature from previous studies. The three previous studies almost have similarities with this research, but what is different with this current research is to observe the citizens of Makassar's social movements on the winning of the empty box.

The volunteer group for winning the empty box in the 2018 Makassar regional head election consists of several groups at each level. Volunteer group "Salamander" with coverage area at the neighborhood level. Volunteer group "Hunter" with coverage area at the hamlet level. Volunteer group "Bombardir" with coverage area at the urban village level. Volunteer group "Terminator" with coverage area at sub-district level. Volunteer group "Komodor" and with coverage area at the city level.

The winning of the empty box against a single candidate pair in general elections is a historical phenomenon and is the first and the only one to date in Indonesia (Detik.com, 2018). The volunteer movement to winning the empty box in the 2018 Makassar regional head election is different from other regional elections. It is interesting to study the social movements that occur after the disqualification of a candidate pair.

This research discusses how the empty box won in the 2018 Makassar regional head election and describes the volunteer movement in various ways to gain mass support and sympathizers in winning the empty boxes in the 2018 Makassar regional head election.

\section{Literature Review}

\subsection{Complaint Theory}

Sidney Tarrow and several other social movement academics modified Marx's class exploitation concept into a complaint theory to analyze social movements and other political resistance forms. Furthermore, Alberto Melucci argues that a movement formed in reaction to new complaints (Sukmana, 2016). 


\subsection{Mobilizing Structures Theory}

Of course, the complaint theory and mobilizing structures roots in social networks, through which the masses and volunteers are recruited and mobilized. McAdam et al. (1996) define mobilizing structures as "mobilizing structures we mean those collective vehicles, informal as well as formal, through which people mobilize and engage in collective action". Mobilizing structures are collective actions carried out formally and informally to mobilize people involved in collective action in social movements.

\subsection{Framing Theory}

In social movements, framing complements the theory of political opportunities and mobilizing structures. Zald argues that cultural tensions and contradictions create complaints and mobilization into a framing process. Framing is also a strategy for achieving the goals of a social movement. Of course, framing requires media. Social movement actors need to frame these actions with slogans and language to stimulate emotion and mobilize the masses and their volunteers. Framing is vital to deliver messages to mobilize the masses and volunteers and gain their support (Situmorang, 2007).

The three theories above are suitable for examining the phenomena in the 2018 Makassar regional head. The complaint theory examines how community disappointment resulted from the disqualification of one of the candidate pairs, making the community feel cheated by the electoral management board. The mass supporters and sympathizers of disqualified candidate pairs turn into empty box volunteers, and disappointed people prefer to vote empty boxes to single candidate pairs.

The mobilizing structures theory examines how this empty box volunteer gathers the masses and sympathizers in winning the empty box. The volunteers' movement in gathering mass and sympathizers through door-to-door to gain local communities support in Makassar. Framing theory examines how empty box volunteers create issues and how the issues spread. In this case, the empty box volunteer uses the issue of "Memilih Kotak Kosong Adalah Sah" (Vote to the Empty Box is Legal) and the tagline "Jangan Biarkan Makassar Mundur Lagi" (Do not Let Makassar Backward Again).

\section{Research Methodology}

This research uses descriptive qualitative methods (Creswell, 2013). Descriptive research is a research method used to describe problems in the present or progress, aiming to describe what has happened at the research time. This research aims to describe the winning of the empty box phenomenon and its volunteer movement in the 2018 Makassar regional head election. The informants in this research were empty box volunteers. Selection of informants using a snowball sampling technique. The number of informants in this research were four empty box volunteers. Each volunteer is a member of four volunteer groups with different levels of coverage. Volunteer group "Salamander" with coverage area at the neighborhood level. Volunteer group "Hunter" with coverage area at the hamlet level. Volunteer group "Bombardir" with coverage area at the urban village level. Volunteer group "Terminator" with coverage area at sub-district level. Volunteer group "Komodor" and with coverage area at the city level.

Data collection in this research through interviews, online media, and literature studies then analyze the data in several stages: data reduction, data display, and conclusion drawing/verifying (Moleong, 2005). 


\section{Results and Discussion}

\subsection{The Emergence of Empty Box Volunteers}

The phenomenon of a single candidate pair against an empty box in Indonesia is not something new in the 2018 simultaneous regional elections. The first single candidate pair emerged in 2015 simultaneous regional elections. However, at that time, the ballot papers will only display options agree and disagree at the bottom of a single candidate pair's picture (Badan Pengawas Pemilihan Umum Republik Indonesia, 2015). Only then, in the next simultaneous regional elections in 2017 and 2018, the ballot papers display a single candidate pair's picture side by side with an empty box (Komisi Pemilihan Umum Republik Indonesia, 2017).

The 2018 simultaneous regional elections are different from the two previous simultaneous regional elections. The difference is that the empty box in the previous simultaneous elections has never won against a single candidate pair. While in the 2018 simultaneous regional elections in Makassar, an empty box won against a single candidate pair. The emergence of the empty box in Makassar regional head election certainly has its dynamics.

The beginning of the emergence of an empty box in the Makassar regional head election is interesting. The Makassar regional head election has two candidate pairs: the first candidate pair, Munafri Arifuddin - Andi Rachmatika Dewi with the acronym Appi-Cicu, and the second candidate pair, Mohammad Ramdhan Pomanto - Indira Mulyasari Paramastuti Ilham, with the acronym Danny-Indira or DIAmi (Kompas, 2018a).

The first candidate pair, Munafri Arifuddin, is the CEO of PSM Makassar and is also the son-in-law of Aksa Mahmud, owner of the Bosowa Group. Aksa Mahmud is the brother-in-law of Muhammad Jusuf Kalla, Vice President of Indonesia, in 2 periods, 2004-2009 and 2014-2019 (Kompas.com, 2017), and his pair, Andi Rachmatika Dewi, member of the South Sulawesi Province of House of Representatives (TRIBUNnews, 2018a). Meanwhile, the second candidate pair, Mohammad Ramdhan Pomanto or Danny Pomanto, is the incumbent, while his pair, Indira Mulyasari Paramastuti Ilham, member of the Makassar City of House of Representatives (Liputan6.com, 2018a).

Danny-Indira is running for candidacy in the Makassar regional head election through individual or independent channels by gathering support from Makassar citizens using photocopies of identity cards. Appi-Cicu runs in his candidacy in the Makassar regional head election through political parties. Political parties that support the Appi-Cicu candidate pair consist of Golkar, NasDem, PDI-P, PPP, PBB, Gerindra, PKS, Hanura, PAN, and PKPI. A large amount of support from political parties for the Appi-Cicu candidate pair made the DannyIndira candidate pair running for candidacy through individual or independent channels. The remaining parties did not have enough seats to support the candidate pair. The General Elections Commission of Makassar City determined candidate pairs through an open plenary meeting on February 12, 2020, at the General Elections Commission Office of Makassar City (Kompas, 2018a).

Drawing the two candidates' official numbers took place at the Grand Clarion Hotel Makassar on February 13, 2020. The Appi-Cicu pair got the official number 1, while the DannyIndira pair got the official number 2. However, several days later, the Appi-Cicu pair's legal team filed a lawsuit against the candidate pair Danny-Indira to the Election Supervisory Board of Makassar City. The lawsuit contains violations committed by Mohammad Ramdhan Pomanto as an incumbent. Appi-Cicu's legal team's lawsuit was related to incumbent policies that violated the regional head election rules for candidacy. Three policies violate the rules; first,

Copyright ( ) 2020. Owned by Author(s), published by Society. This is an open-access article under the CC-BY-NC-SA license. 
cellphones' distribution to all RT/RW head in Makassar city. Second, the appointment of contract workers to become permanent workers in the Makassar city government. Third, the Makassar city government tagline "2X+Baik" (Two Times Better) as the regional head election campaign's tagline (TRIBUNnews, 2018b).

Based on the decision of the State High Court of State Administration which was then followed up by the General Elections Commission of Makassar City, the candidate pair DannyIndira was disqualified from running because they had legally and convincingly violated Law of the Republic of Indonesia Number 10 of 2016 Article 71 Paragraph 3 in conjunction with the 2017 Regulation of General Elections Commission of the Republic of Indonesia Article 89 Paragraph 2 (TRIBUNnews, 2018b).

The incumbent's disqualification has led to the emergence of the empty box and their supporters, called Empty Box Volunteers. Mohammad Ramdhan Pomanto's supporters turn into empty box volunteers. The people of Makassar were disappointed with the disqualification process, which benefited one candidate pair (Appi-Cicu).

Disappointment and pride are a strong impetus for the people of Makassar to win an empty box in the Makassar regional head election. Disappointment with unfair electoral management board made empty box volunteers work hard to prove that empty box can win and become the first history in Indonesia where an empty box win against a single candidate pair in an election. Pride is also one reason for volunteers to win an empty box. Danny-Indira's supporters are entirely humiliated by the Appi-Cicu's supporters, who mock with insulting words because of the disqualification of their candidate pair. Therefore, as the Bugis-Makassar ethnic group, which puts forward the Siri' (pride) culture (Abdullah, 1985), they must maintain their dignity by supporting an empty box and winning the election.

\subsection{Empty Box Volunteer Movement}

The emergence of the empty box volunteer movement as a response complains about the public's disappointment with the unfair election management body. Empty box volunteers move massively and structurally. These volunteers work at the grassroots to seek mass support to select empty boxes. Mass mobilization by empty box volunteers starts from door-to-door socialization to organizational networks' development as the organizational wing.

One of the empty box volunteer movements to gather massive supporters and sympathizers is through door-to-door socialization. The people of Makassar still want Mohammad Ramdhan Pomanto to become Mayor of Makassar because of his performance and achievements during his tenure, such as garden aisles, tourism, city cleanliness, and Adipura's achievements, and other programs. His performance and achievement have motivated the people of Makassar to support an empty box in the Makassar regional head election so that re-election is necessary for 2020. Also, empty box volunteers approach local organizations as volunteer wings for empty boxes to support empty boxes in the Makassar Makassar regional head election.

Regional organizations in the city of Makassar include Laskar Jeneponto, Komunitas Pemuda Utara, Komunitas Turikale, Laskar Karuwisi, Komunitas Massenrengpulu, and other organizations. The local organizations' approach made the empty box volunteer force more strong and massive in the field to seek mass support and sympathizers.

Issues arose regarding the empty box volunteer rode by politicians. According to Arwan, a coordinator of empty box volunteers "Terminator" of Manggala Sub-district, their movement was not ridden by politicians and moved based on disappointment and pride. It is the efforts of volunteers to win an empty box in the Makassar regional head election. Outside of the volunteers, other political movements want an empty box to win.

Copyright ( ) 2020. Owned by Author(s), published by Society. This is an open-access article under the CC-BY-NC-SA license. 
Pride, as one of the triggers that made empty box volunteers works hard to gather the masses and supporters in winning the empty box. Most of the disqualified candidate pair supporters, apart from feeling disappointed, also felt embarrassed by the ridicule from supporters of other candidate pairs.

The Bugis-Makassar ethnic group highly upholds Siri' (pride) (Abdullah, 1985). They are ashamed if humiliated but do not fight back. Therefore one option to fight back is to become an empty box's supporters and defeat a single candidate pair in the Makassar regional head election. They use social networking capital to raise the masses and gain support.

The use of empty box volunteers' social networks aims to increase the mass and sympathizers. The movement was also successful, as the wishes of the people. Apart from gathering mass and sympathizers by door-to-door and approaching regional organizations, empty box volunteers also campaigned in various ways, such as installing banners in the hallways, walls, and fences of citizens' houses. The banner contains the message "Memilih Kotak Kosong adalah Sah" (Vote to the Empty Box is Legal), followed by the hashtag "Lawan Pembegal Demokrasi" (Fight against Democracy Hijackers).

Empty box volunteers also took action on the protocol roads and distributed leaflets to road users. The action was carried out with the theme "Selamatkan Suara Rakyat Makassar dan Menangkan Kotak Kosong" (Save the Makassar People's Vote and Win the Empty Box). The contents of the leaflets distributed contained "Pilih Kotak Kosong dan Mengapa Harus Kotak Kosong" (Vote to the Empty Box and Why Vote to the Empty Box). Almost all activities carried out by empty box volunteers are covered on online media and social media. Public issues promotion through the media has increased the empty box's supporters. The call to win the empty box with the hashtag "Jangan Biarkan Makassar Mundur Lagi" (Do not Let Makassar Backward Again) massive on social media posts.

The empty box volunteers' struggle has paid off where the empty box wins against a single candidate pair. The total votes in the 2018 Makassar regional head election were 565,040 votes. An empty box received 300,795 of the votes (53.23\%), while the Appi-Cicu pair received 262,245 of the votes $(46.77 \%)$, with a difference of 36,898 votes. In the vote's recapitulation, an empty box won in 13 Sub-districts in Makassar city. Meanwhile, a single candidate pair, Appi-Cicu, only won in 2 Sub-districts (Kompas.com, 2018b). In the 2018 Makassar regional head election, the final voter list was 1,019,475 voters, 497,386 (49\%) were male voters and 522,089 (51\%) were female voters (Rakyatku.com, 2018). An empty box officially won the 2018 Makassar regional head election, and as a result, the electoral management board must conduct re-election in 2020.

\section{Conclusion}

The disqualification of one of the candidate pairs, Mohammad Ramdhan Pomanto - Indira Mulyasari Paramastuti Ilham, led to the 2018 Makassar regional elections leaving only one candidate pair Munafri Arifuddin - Andi Rachmatika Dewi. The disqualification of one of the candidate pairs caused the people of Makassar to be disappointed and considered the electoral management board as unfair. These disappointments or complaints sparked political resistance movements. They formed massive grassroots movement groups called empty box volunteers, aiming to win an empty box in the Makassar regional head election and aiming for election organizers to conduct re-election in 2020. Empty box volunteers have also conducted massive campaigns through online media and social media. One of them was an invitation to win an empty box through a Facebook Group with one of the hashtags, "Do not Let Makassar Backward Again." The movement carried out by empty box volunteers was successful and created history for the first time when empty boxes won against a single candidate pair.

Copyright ( $\odot$ 2020. Owned by Author(s), published by Society. This is an open-access article under the CC-BY-NC-SA license. 


\section{Acknowledgment}

The authors are grateful to express gratitude to all of those who have had the pleasure to work during this research conducted, primarily to Universitas Padjadjaran and the Ministry of Youth and Sport of the Republic of Indonesia for their support in this research.

\section{Declaration of Conflicting Interests}

The authors have declared no potential conflicts of interest concerning the research, authorship, and/or publication of this article.

\section{References}

Abdullah, H. (1985). Manusia Bugis Makassar. Jakarta, Indonesia: Inti Idayu Press.

Badan Pengawas Pemilihan Umum Republik Indonesia. (2015, October 21). KPU Tetapkan Model Surat Suara Calon Tunggal Bergambar. Retrieved from https:// bawaslu.go.id/id/berita/kpu-tetapkan-model-surat-suara-calon-tunggalbergambar

CNN Indonesia. (2015, December 10). Pilkada Tiga Daerah Dengan Calon Tunggal Dinilai Lancar. Retrieved from https://www.cnnindonesia.com/nasional/20151210133536-3297294/ pilkada-tiga-daerah-dengan-calon-tunggal-dinilai-lancar

Creswell, J. W. (2013). Penelitian Kualitatif dan Desain Riset: Memilih Diantara Lima Pendekatan. Yogyakarta, Indonesia: Pustaka Pelajar.

Damanik, E. L. (2018). Pemilihan Tanpa Kontestasi: Kotak Kosong Versus Kandidat Tunggal pada Pilkada Serentak 2018 di Kabupaten Deli Serdang. Seminar Nasional Tahunan Fakultas Ilmu Sosial Universitas Negeri Medan Tahun 2018: “Tantangan Yang Dihadapi Dalam Dunia Pendidikan dan Social Studies Di Era Revolusi Industri 4.0," 507-511. Medan, Indonesia. Retrieved from http://digilib.unimed.ac.id/35857/

Darmawan, I. (2017). Peran Dan Strategi Kelompok "Kotak Kosong" Dalam Pilkada Calon Tunggal Kabupaten Pati Tahun 2017: Studi Pendahuluan. Jurnal Wacana Politik, 2(1), 4551. https://doi.org/10.24198/jwp.v2i1.11382

Detik.com. (2017, April 20). Ini 171 Daerah yang Gelar Pilkada Serentak 27 Juni 2018. Retrieved from https://news.detik.com/berita/d-3479819/ini-171-daerah-yang-gelar-pilkadaserentak-27-juni-2018

Detik.com. (2018, December 27). Pertama di Indonesia! Kotak Kosong Menang Pilkada. Retrieved from https://news.detik.com/berita/d-4360870/pertama-di-indonesia-kotakkosong-menang-pilkada

Dirgantara, I. (2015, August 1). Simultaneous regional head elections in Indonesia 2015 - Ifimes. Retrieved from https://www.ifimes.org/en/9052

Gaffar, A. (2006). Politik Indonesia: Transisi Menuju Demokrasi. Yogyakarta, Indonesia: Pustaka Pelajar.

Khaerah, N., Junaedi, J., \& Muslimin, M. (2019). Partisipasi Politik Masyarakat Dalam Diskursus Kolom Kosong Pada Pemilihan Bupati di Kabupaten Enrekang. Gorontalo Journal of Government and Political Studies, 2(1), 16-23. https:// doi.org/10.32662/gjgops.v2i1.497

Komisi Pemilihan Umum Republik Indonesia. (2016, October 6). Pasca Perpanjangan Pendaftaran, 9 daerah Paslon Tunggal, total Pendaftar menjadi 337 Paslon. Retrieved from https:// pilkada2017.kpu.go.id/berita/detail/27

Komisi Pemilihan Umum Republik Indonesia. (2017, September 11). Peraturan Komisi Pemilihan Umum Republik Indonesia Nomor 9 Tahun 2017 Tentang Norma, Standar, 
Prosedur, Kebutuhan Pengadaan dan Pendistribusian Perlengkapan Pemilihan Gubernur dan Wakil Gubernur, Bupati dan Wakil Bupati dan/atau Walikota dan Wakil Walikota. Berita Negara Republik Indonesia Tahun 2017 Nomor 1250. Retrieved from https://jdih.kpu.go.id/data/data_pkpu/9\%20Tahun\%202017.pdf

Kompas.com. (2017, October 28). Golkar Usung Keponakan Jusuf Kalla di Pilkada Makassar.

Retrieved from https://regional.kompas.com/read/2017/10/28/19240091/golkarusung-keponakan-jusuf-kalla-di-pilkada-makassar

Kompas.com. (2018a, February 12). Dua Paslon Pilkada Makassar Ditetapkan, tetapi Tidak Ada Kandidat yang Hadir. from

https:/ / regional.kompas.com/read/2018/02/12/20120521/dua-paslon-pilkada-

makassar-ditetapkan-tetapi-tidak-ada-kandidat-yang-hadir

Kompas.com. (2018b, July 7). KPU Tetapkan Kotak Kosong Sebagai Pemenang Pilkada Makassar 2018 Halaman all - Kompas.com. Retrieved from https:/ / regional.kompas.com/read/2018/07/07/06225871/kpu-tetapkan-kotak-kosongsebagai-pemenang-pilkada-makassar-2018?page=all

Liputan6.com. (2016, February 15). Ini 101 Daerah yang Gelar Pilkada Serentak 2017. Retrieved from https://www.liputan6.com/pilkada/read/2436435/ini-101-daerah-yang-gelarpilkada-serentak-2017

Liputan6.com. (2018a, January 13). 2 Srikandi Cantik Nasdem Bertarung di Pilkada Makassar 2018. Retrieved from https://www.liputan6.com/pilkada/read/3222507/2-srikandicantik-nasdem-bertarung-di-pilkada-makassar-2018

Liputan6.com. (2018b, June 30). KPU: Kotak Kosong Berpeluang Menang Pilkada di 16 Daerah. Retrieved from https://www.liputan6.com/pilkada/read/3572513/kpu-kotak-kosongberpeluang-menang-pilkada-di-16-daerah

Mara, S. (2018). DEMOKRASI KOTAK KOSONG (Studi Kasus Pada Pemilukada Kota Jayapura Tahun 2017). Jurnal Civic Education: Media Kajian Pancasila dan Kewarganegaraan, 2(1), 5464. https:// doi.org/10.36412/ce.v2i1.443

McAdam, D., McCarthy, J. D., \& Zald, M. N. (Eds.). (1996). Comparative Perspectives on Social Movements: Political Opportunities, Mobilizing Structures, and Cultural Framings (Cambridge Studies in Comparative Politics). Cambridge, United Kingdom: Cambridge University Press.

Moleong, L. J. (2005). Metodologi Penelitian Kualitatif. Bandung, Indonesia: PT Remaja Rosdakarya.

Rahman, A. (2007). Sistem Politik Indonesia. Yogyakarta, Indonesia: Graha Ilmu.

Rakyatku.com. (2018, April 18). KPU Makassar Tetapkan DPT, Ini Jumlahnya. Retrieved from https://rakyatku.com/read/97358/kpu-makassar-tetapkan-dpt-ini-jumlahnya

Situmorang, W. A. (2007). Gerakan Sosial: Teori dan Praktik. Yogyakarta, Indonesia: Pustaka Pelajar.

Suara.com. (2015, July 27). Ini Daftar 269 Daerah yang Gelar Pilkada Serentak 2015. Retrieved from https://www.suara.com/news/2015/07/27/104027/ini-daftar-269-daertah-yanggelar-pilkada-serentak-2015

Sukmana, O. (2016). Konsep dan Teori Gerakan Sosial. Malang, Indonesia: Intrans Publishing.

TRIBUNnews.com. (2018a, February 7). PAW Andi Rachmatika Dewi Bersoal, Ini Mekanisme Menurut KPU Sulsel. $\quad$ Retrieved from https:/ / makassar.tribunnews.com/2018/02/07/paw-andi-rachmatika-dewi-bersoal-inimekanisme-menurut-kpu-sulsel?page=all 
TRIBUNnews.com. (2018b, March 21). Inilah Pasal Penyebab Danny-Indira Didiskualifikasi PT TUN, Petahana ini Juga Pernah Merasakannya. Retrieved from https://makassar.tribunnews.com/2018/03/21/inilah-pasal-penyebab-danny-indiradidiskualifikasi-pt-tun-petahana-ini-juga-pernah-merasakannya

Widyasari, A., Dewi, R. A., \& Rengganis, V. M. S. (2019). Gerakan Politik Pendukung Kotak Kosong: Keterlibatan Civil Society dalam Pilkada Kabupaten Pati Tahun 2017. Jurnal PolGov, 1(1), 89-119. https:// doi.org/10.22146/ polgov.v1i1.48307

\section{About the Authors}

1. Harianto, obtained his Bachelor degree in Political Science from Universitas Islam Negeri Alauddin, Makassar, Indonesia, in 2016. The author is a graduate student at Master of Political Science, Faculty of Social and Political Sciences, Universitas Padjadjaran, Indonesia. E-Mail: harianto18001@mail.unpad.ac.id

2. Wawan Budi Darmawan, obtained his Doctoral degree in International Relations from Universitas Gadjah Mada, Indonesia, in 2017. The author is an Assistant Professor at the Department of International Relations and the Head of Master of International Relations, Faculty of Social and Political Sciences, Universitas Padjadjaran, Indonesia.

E-Mail: wawan.budi.darmawan@unpad.ac.id

3. Muradi, obtained his Doctoral degree from Flinders University, Adelaide, Australia, in 2012. The author is a Professor of Political Science and Security Studies at the Department of Political Science, Faculty of Social and Political Sciences, Universitas Padjadjaran, Indonesia. E-Mail: muradi@unpad.ac.id 